\title{
IMPLEMENTATION OF ISLAMIC BUSINESS ETHICS ON SMALL AND MEDIUM-SIZED ENTERPRISES (SMEs): CASE STUDY OF SMEs XYZ
}

\author{
Amimah Oktarina1, Amir Mu'alim² \\ 1Post-Graduated Student, Master of Islamic Studies, Faculty of Islamic Studies, Islamic \\ University of Indonesia, Yogyakarta 55281, Indonesia \\ ${ }^{2}$ Lecturer, Faculty of Islamic Studies, Islamic University of Indonesia, \\ Yogyakarta 55281, Indonesia \\ Correspondence E-mail: mimitari92@gmail.com
}

Received: July 2017, Accepted: October 2017

\begin{abstract}
The rapid growth of Small and Medium-sized Enterprises sector (SMEs) in Indonesia increases business competition become strict and complicate among them. Competition of existing businesses tends to be unhealthy and ignore the ethical values. It makes the discourse of business ethics at SMEs is indispensable in order to form the basis for operations and avoid deviations ethical values. As a manufacturer of fish processing has been certified halal by the MUI, SMEs XYZ should be able to apply Islamic business ethics in its activities. So it is not only profit oriented, but also pay attention to ethical values. This study aimed to describe the implementation of Islamic business ethics which consists of four (4) axioms which are unity, equilibrium, free will, and responsibility in SMES XYZ. The method used in this research is descriptive qualitative analysis through the 4 (four) stages of data collection, data reduction, data display, and conclusion. The result in this study is SMEs XYZ was implemented Islamic business ethics on its operations.
\end{abstract}

Keywords: business competition, Islamic business ethics, SMEs

JEL Classification: M21, Z12, P31

\begin{abstract}
Abstrak: Pesatnya pertumbuhan sektor Usaha Kecil dan Menengah (UKM) di Indonesia meningkatkan persaingan usaha menjadi ketat dan kompleks di antara mereka. Persaingan bisnis yang ada cenderung tidak sehat dan mengabaikan nilai etika. Hal itu membuat wacana etika bisnis di kalangan UKM sangat diperlukan agar bisa membentuk pondasi untuk beroperasi dan menghindari penyimpangan nilai etika. Sebagai produsen pengolahan ikan yang telah mendapat sertifikasi halal oleh MUI, UKM XYZ harus bisa menerapkan etika bisnis syariah dalam aktivitasnya. Jadi tidak hanya berorientasi pada keuntungan, tapi juga memperhatikan nilai etika. Penelitian ini bertujuan untuk mendeskripsikan penerapan etika bisnis syariah yang terdiri dari empat (4) prinsip, yaitu kesatuan, ekuilibrium, keinginan untuk bebas, dan tanggung jawab di UKM XYZ. Metode yang digunakan dalam penelitian ini adalah analisis deskriptif kualitatif melalui 4 (empat) tahap pengumpulan data, reduksi data, tampilan data, dan kesimpulan. Hasil dalam penelitian ini adalah UKM XYZ menerapkan etika bisnis Islam dalam operasinya.
\end{abstract}

Kata kunci: persaingan bisnis, etika bisnis syariah, UKM

Klasifikasi JEL: M21, Z12, P31 


\section{INTRODUCTION}

Indonesia, which is one of the developing countries continue to perform various economic activities to support the sustainability of national development. Growing SMEs in Indonesia contribute to the national economy.

According to Irfan that Small and Medium-sized Enterprises sector (SMEs) in the economy of a country plays an important role. ${ }^{1}$ Indication that the strategic role of small and medium micro enterprises that can be seen from its contribution to GDP, non-oil exports, employment, and improving the quality of human resources is significant.

As a country which has a Muslim majority population, the Indonesian government gives special attention to SMEs in particular domestic products with the halal certificate from MUI. As we know that Islam justifies the trade, commerce and or purchase and therein also entered the business. ${ }^{2}$

Efforts to address the deviation values in modern business practices, business ethics has long appeared be explored in greater depth in Islamic literatures. Business ethics becomes talk of interest in line with the growth and development of business competition. On an international scale, the researchers measure of business ethics in the European region through business ethics index. The study was conducted by John Tsalikis and Bruce Seaton (2007)3, namely: The study expands the systematic measurement of consumers' sentiments towards ethical business practices to the international arena, the data for the Business Ethics Index (BEI) were gathered in three countries of the European Union (UK, Germany, Spain).

\footnotetext{
${ }^{1}$ Irfan, Muhammad, Prinsip-Prinsip Perumusan Kebijakan Negara, (Jakarta: Sinar Grafik, 2000)

${ }^{2}$ Johan Arifin, Etika Bisnis Islam, (Semarang:Walisongo Press, 2009), pg. 81.

${ }^{3}$ John Tsalikis and Bruce Seaton (2007), "The International Business Ethics Index: European Union”, Journal of Business Ethic, pp. 229-238
}

In the view of Islam, more commonly is known ethical behavior. ${ }^{4}$ Virtue is one of the three basic frameworks of Islamic teachings. Morals have a very important position because of morality is the fruit produced from the process of applying aqidah and shariah. Like a building, morality is the perfection of the building after the building foundation and strong.

The scope of morals is very broad, covering all aspects of human life both vertically to God, as well as horizontally. Yunahar Ilyas modify the scope of morals over into several parts, namely5: the morals of Allah SWT, the character of the Prophet Muhammad, the personal morals, morals in the family, social morals, and morals state.

The sections within the scope of morals are promoted by Yunahar Ilyas is the specialization of the scope of the very broad character. In this study, the authors divide the scope of morals in three parts which are assumed to represent other parts. As previously is disclosed that the character deals with man's relationship with God fellow human beings and nature.

Morals in Islamic business ethics are shown by some business people based on the teachings of Islam. Indeed, the Qur'an has provided a reference for businesses in running or managing an Islamic business. According to Muhammad Djakfar, Islamic business ethics are ethical norms-based Al-Qur'an and hadith should be used as a reference by anyone in business activity. ${ }^{6}$ In other words, ethics-based business however holy book and the Sunnah of the Prophet Muhammad, as well as modern business ethics, not quite seen partiality alone, but needs to be seen also in its function as a whole (holistic). In the sense of business ethics

${ }^{4}$ Murti Sumarni and John Shuprihanto, Pengantar Bisnis, (Yogyakarta: Liberty, 1995), pg. 21

${ }^{5}$ Yunahar Ilyas, Kuliah..., pg. 6

${ }^{6}$ Muhammad Djakfar, Etika Bisnis Islam, (Malang: UIN Malang Press), 2008, pg. 84. 
of Islam needs to be positioned as a commodity that can be spawned an academic scientific branch, as well as the guidance of businessmen in performing everyday activities. ${ }^{7}$

The cornerstone of Islamic normative business ethics should contain at least four cornerstone elements in the system of ethics, namely8: unity, equilibrium, free will and responsibility.

Many people give a definition of the Small and Medium-sized Enterprises (SMEs). This is because it is not surprising considering that many parties are also interested in the SMEs so that each of them provides a definition in accordance with the criteria created by itself. However, in this case, the authors take two definitions of Small and Medium-sized Enterprises (SMEs), known in Indonesia, namely the definition under the Act (UU) No. 20 in 2008 and the Central Statistics Agency (BPS).

The role of SMEs is very strategic and important from many aspects. First, a large number of industry and found in every sector of the economy. Second, its great potential is in creating more jobs than the same investment in the business on a bigger scale. Thirdly, the contribution of SMEs to GDP is significant. Fourth, have a contribution to foreign exchange with export value stable.

One of SMEs run by Muslim businessmen and obtain halal certificate from MUI in Yogyakarta are SMEs XYZ located in Nayan, 18 Maguwoharjo. SMEs $\mathrm{XYZ}$ is engaged in fish processing which began production in July 2012. The industry is made of many kinds of processed fish-based tilapia.

As a manufacturer of fish processing has been certified halal by the MUI, SMEs XYZ should be able to apply Islamic business ethics in its activities. Thus, in the process of implementation of its activities, not only focused on the achievement of profit, but also pay attention to ethical values. It is in the spotlight of interest to researchers in the SMEs is the slogan of "lawful and well". However, the SMEs XYZ have their differences given to the wage system of labor vary from one another even though they have the same task. Moreover, the production process is often timeconsuming labor of worship so often labor late for praying. SMEs XYZ also requires the use of the veil for all women workers.

The problem is formulated in this research is how the implementation of Islamic business ethics at SMEs XYZ? The research objective was to describe the implementation in Islamic business ethics at SMEs XYZ.

\section{RESEARCH METHOD}

This research is a field research as research carried out intensively, detail, and depth to the particular object. The field research is in-depth study of the particular social unit that results of the study provide a broad overview and deep understanding of a particular social unit. ${ }^{9}$

\section{Research sites}

SMEs XYZ located in Solo Km 8 Jalan Dusun Nayan, Maguwoharjo village, Depok, Sleman, Yogyakarta. UPI is built on an area of $200 \mathrm{~m}^{2}$. This study chose this because SMEs XYZ is a SME which is recommended by the government of Yogyakarta in motion "GEMARIKAN" and the slogan "clean and healthy". SMEs also as an institution that seeks to empower the community's economic activities around workforce is predominantly Muslim.

\section{Informants}

Informants in this study as many as five (5) persons. 5 of informants are already considered representative to be used as research informants.

Data collection technique

\footnotetext{
${ }^{7}$ Muhammad Djakfar, Etika..., pg. 85

${ }^{8}$ Muslich, Etika Bisnis..., pg. 30-44
}

${ }^{9}$ Sudarwan Danim, Menjadi Peneliti Kualitatif, (Bandung: Pustaka Setia, 2002), pg. 55 
Primary data were obtained from observations and interviews. The results of the data collection will be used as the primary source in this study. While secondary data in this study are the data obtained from the writings or books that are relevant to the topic of research and support in elaborating the concept of Islamic business ethics at SMEs which will be used as a reference.

Data analysis technique

In answer to the first problem formulation in these study researchers used a model of interactive data analysis by Miles and Huberman. Data analysis model has four stages, namely the first stage of data collection, data reduction the second phase, the third phase of the display data, and the fourth stage inference and data verification.

\section{RESULTS AND DISCUSSION}

\section{Unity}

To know the implementation of Islamic business ethics at SMEs XYZ, found that of 5 (five) respondents were interviewed in this study, some of them when prayer time came to do is urge to pray. As revealed by Mrs. Rini10: "When doing production and had not arrived already reverberating recess while the noon call to prayer, then immediately left for a moment of prayer and production activities. When it has finished the prayers immediately continue the work that was left was to be quieter. "

In addition, Ms. Atun is labor in SMEs XYZ that have Job Description knead the dough for raw materials to be produced. Knead job is a job that is quite heavy because the kneading process is still done manually. Therefore, if it is in the process adzan then knead and labor often cannot rush the prayers.

In order to facilitate the employment of worship, as a manager and also serve as labor on these SMEs, Mr Heri provide worship

\footnotetext{
${ }^{10}$ Interview by Mrs. Rini, Yogyakarta, 11 November 2016
}

facilities in the form of a single special room laid out for a place of worship. According to him ${ }^{11}$ : "The labor work for 8 (eight) hours per day, even though their house located not too far from the location of these SMEs, but only 1hour rest (hours) used to rest on SMEs just like eating and prayer. Therefore, to support the comfort of prayer it provided a special room for prayer."

Availability of worship facilities for workers means that the business makes it easy for workers to worship. Additionally, by providing a special room for worship, it will provide comfort for workers to practice their religion. As we know that often the business is run by the setting or the layout on site were nice, but the room for worship only use the rest of the area alone.

Initiative carried out by workers in SMEs is to have a special room for worship indicates that as business people who are Muslims, then worship is something that must be considered so that the workers also feel calm and comfortable.

SMEs XYZ has a workforce that is predominantly Muslim. In addition to not leaving prayers in the operation, the workforce has an activity regularly every morning before carrying out the work of prayer. Pray before and after work indicates that as a creature of Allah, human beings have a vertical relationship to Him. Everything was done solely for the pleasure of Allah SWT expect. By praying means that their unconditional surrender of man before God Almighty to make wishes, and everything he does on Allah's command.

In its production activities, Tilapia is the main product and mainstay on SME obtained by maintenance done by managers of SMEs. As revealed by Mr. Heri that ${ }^{12}$ : "Tilapia fish seed is well maintained as a routine feeding and

\footnotetext{
${ }^{11}$ Interview by Mr. Heri, Yogyakarta, 11 November 2016

${ }^{12}$ Interview by Mr. Heri, Yogyakarta, 11

November 2016
} 
keeping tilapia where water conditions are maintained. Tilapia fish are nurtured to become baby tilapia within two months. The moment has become a baby tilapia then ready to be produced. We chose maintain its own tilapia with no supply of this item to another party for baby tilapia is our flagship product maintains itself more so with guaranteed quality. "

As SMEs engaged in the processing of fish, then fish as a key raw material in the product must be guaranteed quality. SME managers opt to do their own maintenance tilapia fish to be baby tilapia is the right step. This is because it does not want to carelessly in the use of raw materials. Moreover, it is well known that often occur sales of fish that are not fit for consumption (rotten).

As head of production, Ms. Ning has a big responsibility towards processed products. Therefore, check the ingredients before use is the job he does in addition to preparing the recipe in accordance with the proportion. Supplementary materials obtained from suppliers that are trusted. In addition, the use of raw materials such as onions, carrots for mixed product use fresh ingredients.

In addition to producing products that are lawful and good, the cornerstone of monotheism as the embodiment of Islamic business ethics at SMEs is also applied by the workforce in allocating their wages. The informants familiar with Islamic teachings about charity, infaq, and alms. They also realize that the wages earned there is another man's treasure that must be channeled through the ritual. Not only the implementation of the teachings of Islam but for them to tithe and infaq will provide peace and blessings for themselves.

As a business engaged in the management of fish and has a daily production target, MSMEs are still watching the welfare of workers by imposing a holiday in operation at the time of celebration of the Islamic religion. This means that these SMEs to actively participate in religious events enliven. In addition, management also provides room for workers to be active in religious activities in the neighborhood.

\section{Equilibrium}

In business activities, equilibrium has become known as the foundation should be applied. Businesses that do not only involve one party but also many parties such as customers and suppliers should be based on the principle of fairness. According to Mrs. Rini ${ }^{13}$ : "SMEs products are sold to consumers are diverse ranging from housewives, traders school snack, and supplying to shopping. Many are also consumers who come directly to SMEs to buy, we treat customers fairly by not discriminating them from, any work, or religion. "

Justice is a manifestation of horizontal relations among humans. As a business person, be fair must be upheld in order between the parties is not social tension. Not only among consumers, among workers also work on the basis of justice.

The age difference among the labor is not a reason to discriminate types of duties. In this SME division of labor is clear, but will be flexible if there are workers who are unable to do so. Islam requires its adherents to be fair and do well. And even justice must take precedence over doing well. In business, the most fundamental requirements of fair is in determining the quality (quality) and the size (quantity) at any dose or scales. This is what Allah says, in the Qur'an Surah Al-An'am: verse 152.

In producing the product, the dose of quality and quantity should be fair. Products manufactured, will be packed in accordance with the type and severity. The concept of balance is applied by workers in the fish processing SMEs is a manifestation of the principle of fair promoted by Islam in the trade. The products are sold very well maintained and

\footnotetext{
${ }^{13}$ Interview by Mrs. Rini, Yogyakarta, 11
} November 2016 
measuring quality. So, consumers will not do complain to the product. The resulting product is marketed with a friendly price. This means that in setting the price, the SMEs into account the earnings expectations are not excessive.

Pricing is done in accordance with the type, quality and product dosing means that SMEs have applied the principles of justice, especially in making the profit margin. So, although this profit-oriented business, but also pay attention to customer satisfaction with the consideration of appropriate pricing with products. The concept of balance is applied in SMEs are the remuneration in accordance with the working hours of labor each. No labor within the working hours for permission to specific interests and it becomes a consideration in awarding the amount of his wages.

Based on these results, it means that SMEs have applied the concept of fairness in the determination of wages to workers. The big difference in the amount of wages received it because of differences in working hours of labor. Tolerance given by the SMEs to labor for a permit at the time of working hours are also balanced with the consequences in the reception amount of wages. So that feels fair labor between the sallary systems is implemented.

\section{Free Will}

The production process is carried out by SMEs UPI Mino Ngudi Lestari in producing the fish processed into products processed fish with various kinds of processing based on the stage that has been set forth in the company SOP. In producing its products, SMEs have to apply the principle of efficiency. As we know that if it is associated with the production process of a product, it can be interpreted as an efficient production process that produces a product with good quality with the raw materials used by the correct amount.

Recipe used on every working day in accordance with the product to be manufactured on the day. In the recipe included the name of the material used and the amount of dose. In addition, the labor force is also concerned about the quality of the materials used for the production in order to produce a quality product. The dose of material that has been set in accordance with a prescription product would interfere with production. Accuracy of labor in preparing the materials used for the production is very important. This is because SMEs XYZ required to produce a processed fish product quality.

The principle of efficiency in using of production materials is important in the SME workforce. Just as a fish fillet preparation done by manpower on a weekly basis. Working system applied by SMEs has been to maximize efficiency in use of resources. By buying the fish and process fish fillet on each weekend, then workers can minimize the use of resources such as a milling machine is done only once (repeatedly). In addition to doing fillet of fish, they do alonely. It's meaning the amount of spending to buy fish has not been fillet so that they can save expenditure on these SMEs.

When viewed from the values of Islamic business ethics, then even though the workforce has the freedom to use the resources in production but still carries the principle of efficiency in order to avoid useless. Freedom for labor does not mean they pleased in utilizing existing resources in the business, but remained in the corridors of a special order to manufacture products with high quality and efficient.

Additionally, as a business person engaged in domestic food industry SMEs XYZ is expected to create a creative innovation in its products. Innovation can also trigger businesses to produce better products and competitive. The market demand is also affecting the ability of product innovation for SMEs. Market demand for the products offered can trigger innovation of the product. As well as the SMEs that provides free space for the workforce to innovate. The benefit is that the products have 
been innovated be accepted by the market and is able to competitiveness.

In the perspective of Islamic business ethics, product innovation than as a form of realization of the free will of businesses, product innovation is also a manifestation of the increased service needs of the community. As we know that economic activity is individual worship, while producing in this case the product innovation is a social obligation.

Ethical values shown by SMEs are to be open to education, especially in the field of research. In addition, SMEs have also received student interns who want to develop themselves and gain practical knowledge in the field of fish processing. As mentioned above, that these SMEs often receive guests from various areas that are usually community food industry to share their experiences.

Not many SMEs are open to research or academic visits, but SMEs provide free space for anyone who wants to share the experience and knowledge to visit and see firsthand the production process. SMEs also estimated specially processed fish travel.

\section{Responsibility}

The cornerstone of the responsibility that is part of the foundation of Islamic business ethics when reflected in the activities of the business, the business is not only responsible for the work, but the essence of this responsibility more broadly that is accountable to God, others, and the environment.

Ethical values can be seen from how much sense of responsibility carried by the business. In business, so that its activities can be run well and improve the effectiveness and efficiency of the Standard Operating Procedure (SOP) is necessary.

SOP serves as the standardization of the way performed by workers in completing its tasks. With the SOP, the level of errors and omissions can be minimized thus increasing the efficiency and effectiveness of the implementation of the tasks and responsibilities of the workforce as a whole.

Businesses engaged in fish processing as a raw material and the other mixture ingredients should be mixed in with either susceptible to failure in producing it. Therefore, the SOP will facilitate labor in performing their duties so that errors can be minimized. In addition, the tools used are also in accordance with its function so that the SOP can facilitate manpower to operate these tools in order to function properly.

The company apply employment in accordance with SOPs indicate that the workforce has the responsibility for the job. That is, the works there are standards that must be met and not arbitrary in the act. The use of materials and equipment at the company must be considered because if it is not according to the SOP, there will be things that are not desirable, such as accidents. Progressed well a business is the application of the rules for labor. This is so that their discipline for workers. Regulations in SMEs is usually made by the manager so that all units in the organization with the work continuously and consistently. SMEs UPI Mino Ngudi Lestari is unique in enforcing regulations for workers.

As the fish processing units, these SMEs impose the use of headscarves for employees during work. In addition, SMEs have special uniforms obtained from Pertamina's CSR. The workers are also required to use a large boot and standardized for the industry and designed safety for workers.

The embodiment of the values of responsibility for the businessman indicated to compliance with regulations applicable to the business. Regulations made in order to be properly implemented due to the regulations, the business can run with a harmonious, consistent, and the achievement of business goals. However, based on interviews over the SMEs do not have the strict sanctions for workers who violate the rules. As revealed by labor on top of that they have not seen any sanctions imposed if they violate the rules. 
However, the fact that so far, the work force continues to comply with regulations in the SMEs.

Types of products are produced on a daily basis requires the dexterity of the workforce in order to take advantage of time as possible so that tasks can be completed on target (quantity) and time. It is a manifestation of the responsibility of businesses to be consistent with the target set within a certain period. So, the time could be used to the maximum with optimal results anyway.

The responsibility of a businessman is to convey product information to consumers. In this case, SMEs engaged in fish processing presents information clearly and what the packaging according to the materials used. Labor maintains the quality of products by packaging the product in accordance with standard. This means that the packaging ensured safety guarantee product quality. Good Quality use of plastic packaging, labeling in accordance with expiry dates, names, and packed with a special machine packing indicates that the workforce has a high sense of responsibility towards the products that will be distributed to consumers.

Moreover, it is well known, the products that is made from fish meat is very susceptible to cases of fake meat or meat used is not suitable for consumption. However, in this case SMEs XYZ slogan "clean and healthy" on its products this means that SMEs take full responsibility for halal and health products through the production process does.

In the course work problems can arise both internally and externally. However, the problem is not regarded as a source of disharmony in the business. Businessman is responsible for solving problems intelligently and wisely.

Ethical values contained in a business can be seen the extent to which the business is implementing four business ethical foundation of Islam in its business activities. The increasingly fierce competition requires businesses undertaken have characteristics that can be added value. SMEs today have great potential to be developed as a great contribution to the national economy, should carry the ethical values in its business activities. As has been implemented by SMEs UPI XYZ as a fish processing unit known in Yogyakarta that has been observed from the Islamic business ethics, SMEs have applied foundation of Islamic business ethics.

\section{CONCLUSION}

Based on the research and discussion above, we can conclude several things, namely SMEs XYZ as a fish processing unit has all the Muslim workers and carries the slogan halal and healthy products have been applying Islamic business ethics in its business activities. Four grounding a benchmark application of business ethics Islam is monotheism, balance, free will, and responsibility has been implementation on the business activities of SMEs XYZ. As an answer to the problems interesting in this study is the difference in the wages system for the workforce that embodies the values of Islamic business ethics is the cornerstone of balance where the workforce that does permit in during working hours and on an ongoing basis the number of wage cuts.

This study examines the application of Islamic business ethics in businesses, especially SMEs are seen as institutions of economic empowerment should be given added value in order to compete so that the results of this study are expected to be input for the business person in applying ethical values in business.

\section{REFERENCES}

Arifin, Johan. Etika Bisnis Islam. Semarang:Walisongo Press. 2009

Danim, Sudarwan. Menjadi Peneliti Kualitatif. Bandung: Pustaka Setia. 2002

Djakfar, Muhammad. Etika Bisnis Islam. Malang: UIN Malang Press. 2008

Ilyas, Yunahar. Kuliah Akhlaq. Yogyakarta: LPPI. 2014 
Irfan, Muhammad. Prinsip-Prinsip Perumusan Kebijakan Negara. Jakarta: Sinar Grafik. 2000

Muhammad. Etika Bisnis Islami. Yogyakarta : Unit Penerbit dan Percetakan Akademi Manajemen Perusahaan YKPN, 2004

Muslich. Etika Bisnis Islami. Yogyakarta : Ekonisia Kampus FE UII, 2004

Naqvi, Syed Nawad Haidar. Mengagas Ilmu Ekonomi Islam, terj. M. Saiful dan Muhammad Ufuqul Mubin. Yogyakarta: Pustaka Pelajar. 2003

Sumarni, Murti dan John Shuprihanto. Pengantar Bisnis. Yogyakarta: Liberty. 1995

Tsalikis, John and Bruce Seaton (2007), "The International Business Ethics Index: European Union", Journal of Business Ethic, pp. 229-238 